\title{
26. PLIOCENE DISCOASTER ABUNDANCE VARIATIONS, DEEP SEA DRILLING PROJECT SITE 606: BIOCHRONOLOGY AND PALEOENVIRONMENTAL IMPLICATIONS ${ }^{1}$
}

\author{
Jan Backman, Department of Geology, University of Stockholm \\ and \\ Pierre Pestiaux, Institut d'Astronomie et de Géophysique Georges Lemaitre, Université Catholique de Louvain ${ }^{2}$
}

\begin{abstract}
Abundance variations of six Pliocene species of the calcareous nannofossil genus Discoaster have been determined for the time interval between 1.9 and $3.6 \mathrm{Ma}$ at DSDP Site 606, using a sample interval of $30 \mathrm{~cm}$ ( $<9 \mathrm{kyr}$.). These quantitative data contain information which can be interpreted in terms of both biochronology and paleoclimatic development. The following datums have been examined: $D$. brouweri (extinction at $1.89 \mathrm{Ma}$ ), D. triradiatus (extinction at $1.89 \mathrm{Ma}$ ), $D$. triradiatus (peak abundance begins at $2.07 \mathrm{Ma}$ ), D. pentaradiatus (extinction between 2.33 and $2.43 \mathrm{Ma}$ ), D. surculus (extinction between 2.42 and $2.46 \mathrm{Ma}$ ), D. asymmetricus (sharp decline in abundance at $2.65 \mathrm{Ma}$ ), and $D$. tamalis (extinction at $2.65 \mathrm{Ma}$ ). The age of the peak abundance of $D$. triradiatus is accurately determined for the first time. The remaining estimates agree with those previously obtained from the northern North Atlantic and Pacific oceans.

Plots of changes in total Discoaster accumulation rate indicate a long-term trend of progressive cooling of sea-surface temperatures during preglacial times in the area of Site 606 . This trend is overprinted by short-term abundance oscillations. The orbital forcing of paleoclimatic change is strongly imprinted on these short-term variations, as indicated by spectral analysis. The $413-\mathrm{kyr}$. eccentricity period, the $41-\mathrm{kyr}$. obliquity period, and the 23 - and 19 -kyr. precessional periods (not separated in our record) are identified, and the eccentricity period is dominant. The eccentricity period coincides with sharp changes in the Discoaster record at 2.3-2.4 Ma, 2.7-2.8 Ma, 3.1-3.2 Ma, and 3.5-3.6 Ma. Only the youngest of these cycles can be linked with major glacial buildup.
\end{abstract}

\section{INTRODUCTION}

Drilling on DSDP Leg 81 provided the first accurate age estimate of the initiation of large-scale Cenozoic glaciation in the high-latitude North Atlantic region. The age derived from Hole $552 \mathrm{~A}$ is approximately $2.4 \mathrm{Ma}$, and the evidence for the passing of this paleoclimatic threshold is based on the first occurrence of ice-rafted material in the sediment record and oxygen-isotope analyses (Shackleton et al., 1984). The isotopic data of Shackleton et al. (1984) indicated also that the preglacial Pliocene was characterized by considerable climatic variability, although no information was obtained on the development of sea-surface temperature changes, since benthic foraminifers were analyzed. Subsequently, Backman et al. (in press) addressed the question of Pliocene sea-surface temperature development through analysis of abundance variations of the calcareous nannofossil genus Discoaster from the sample set used by Shackleton et al. (1984). These warm-water-preferring nannofossils occurred in distinctly low relative abundances at the latitude of Hole $552 \mathrm{~A}\left(56^{\circ} \mathrm{N}\right)$, but oscillated in abundance at a periodicity corresponding to one of the main orbital elements (obliquity). Variation in the tilt axis of Earth is strongly related to insolation changes at higher latitudes, and is therefore associated with temperature change (see, e.g., Berger and Pestiaux, 1984). Hence, the data of Backman et al. (in press) indicate that short- and long-term paleoclimatic change may be delineated by determining Discoaster abundance oscillations.

\footnotetext{
${ }^{1}$ Ruddiman, W. F., Kidd, R. B., Thomas, E., et al., Init. Repts. DSDP, 94: Washington (U.S., Govt. Printing Office)

2 Addresses: (Backman) Department of Geology, University of Stockholm, S-106 91 Stockholm, Sweden; (Pestiaux) Institut d'Astronomie et de Géophysique Georges Lemaitre, Université Catholique de Louvain, Louvain-la-Neuve, Belgium.
}

Before DSDP Leg 94, DSDP Hole 552A was the only Neogene sequence successfully cored in the mid- and highlatitude North Atlantic region using the Hydraulic Piston Corer. This is a poor record of deep-sea drilling for paleoenvironmental purposes in the North Atlantic Ocean, considering that this region was of key importance for global oceanographic and climatic development during late Cenozoic times (see, e.g., Ruddiman and McIntyre, 1984). The Leg 94 sites were chosen to give good latitudinal coverage in the North Atlantic and to provide sequences of relatively high sediment accumulation rates.

The primary purpose of the present study is to evaluate further the usefulness of the nannofossil genus Discoaster as an indicator of sea-surface temperature change. This evaluation includes spectral analysis to investigate whether the paleoclimatic forcing of all main orbital elements (eccentricity, obliquity, precession) is imprinted on the Pliocene Discoaster record. Such an evaluation has to be based on quantitative data gathered from closely spaced samples. In turn, this strategy promises to add valuable biochronologic information regarding the Pliocene Discoaster extinction events. Of the Leg 94 sites drilled, we chose to study the southernmost (Site 606, $37^{\circ} \mathrm{N}$ ), mainly because the data generated would represent different paleoceanographic and paleoclimatic conditions, as compared with Hole $552 \mathrm{~A}\left(56^{\circ} \mathrm{N}\right)$.

Site 606 is situated in the subtropical gyre at latitude $37^{\circ} \mathrm{N}$ and longitude $35^{\circ} \mathrm{W}$; the water depth is $3007 \mathrm{~m}$. The moderate water depth and the fact that Discoaster spp. are among the least dissolution-susceptible of all Cenozoic nannofossils (Lohmann and Carlson, 1981) suggest that the influence of dissolution on our abundance data is negligible. A sample interval of $30 \mathrm{~cm}$ has been used, representing roughly $8.9 \mathrm{kyr}$. above the base of the Mammoth and about $4.5 \mathrm{kyr}$. below that boundary. The 
taxonomy of the species involved, and the counting method adopted, are discussed by Backman and Shackleton (1983). The chronology adopted results from combined magnetostratigraphic data (Clement and Robinson, this volume) and biostratigraphic data (this study). We have not used material from Hole 606A. Because our principal interest was to compare the results from Site 606 with those obtained from Hole 552A, we have investigated the same time interval, between approximately 1.9 and $3.6 \mathrm{Ma}$. The time-control for the spectral analysis is based on linear interpolation between the magnetostratigraphic control points.

\section{BIOCHRONOLOGY}

The succession of late Pliocene Discoaster extinction events was established more than a decade ago (e.g., Bukry, 1973), and the abundance patterns from Site 606, shown in Figure 1, do not deviate from this order (from oldest to youngest): $D$. tamalis, $D$. asymmetricus, $D$. surculus, $D$. pentaradiatus, and $D$. brouweri. However, the precise chronology of Pliocene Discoaster extinction events has been much debated. In the sediment record of Site 606, several factors provide a good basis for precise chronological estimates of the Discoaster datums: the comparatively high sediment accumulation rate, the recognizable presence of all relevant magnetostratigraphic reversal boundaries, the fact that these boundaries occur over short stratigraphic intervals, and the short sample intervals used.

The investigated Discoaster datums all occurred in the late Gauss and early Matuyama. The age-depth relationships of the base of the Olduvai, top of the Gauss, and top of the Kaena suggest a uniform sediment accumulation rate of approximately $3.4 \mathrm{~cm} / \mathrm{kyr}$.

\section{D. tamalis and D. asymmetricus}

Backman and Shackleton (1983) demonstrated that $D$. tamalis and D. asymmetricus exhibited pronounced covariation in abundance patterns during mid-Pliocene times in the equatorial Pacific (V28-179) and the North Pacific (V32-127). Backman et al. (in press) also noticed this covariation in the high-latitude North Atlantic Ocean (DSDP Hole 552A). The mid-Pliocene record at Site 606 (Fig. 1) also shows a high degree of covariation between these two species, suggesting that this pattern of covariation probably occurred on a global scale and that a close taxonomic relationship probably existed between D. tamalis and D. asymmetricus.

The results from V28-179, DSDP Hole 552A, and Site 606 suggest that $D$. tamalis began to become numerically important at approximately the Gauss/Gilbert boundary. It also appears from these sequences, however, that the first appearance of $D$. tamalis is less useful from a biochronologic point of view, owing to low and gradually increasing abundances in the early part of its range. Toward the ends of their ranges, the abundance patterns obtained at Site 606 are remarkably similar to those observed in Core V28-179. Both D. tamalis and D. asymmetricus showed a mutual and clear abundance decline at about $2.65 \mathrm{Ma}$ in both oceans. The latter species, however, continued into the early Matuyama but showed an abundance which was less than $10 \%$ of its mean value in the pre-2.65-Ma record. The virtual absence of $D$. tamalis in the post-2.65-Ma record both at Site 606 and in Core V28-179 suggests that the presence of D. asymmetricus above a level corresponding to $2.65 \mathrm{Ma}$ is indigenous and not caused by sediment mixing. For this reason it is not possible to assign a precise chronological estimate for the true last occurrence of $D$. asymmetricus. Nevertheless, the abundance decline at 2.65 Ma appears to provide a consistent datum in the Atlantic and Pacific oceans for both species, which can be easily determined using a quantitative method of investigation.

\section{D. surculus and $D$. pentaradiatus}

Comparison of abundance patterns of $D$. surculus and D. pentaradiatus in different cores and ocean basins (Figure 1; Backman and Shackleton, 1983; Backman et al., in press) suggests that the last occurrences of these two species provide only approximative biochronological information. All available data suggest that these extinctions occurred in the earliest part of the Matuyama, between approximately 2.35 and $2.45 \mathrm{Ma}$, and that $D$. surculus usually disappeared slightly earlier than $D$. pentaradiatus. In the record of DSDP Hole 552A, for example, D. surculus disappeared in conjunction with the entry of the first ice-rafted pulse and $D$. pentaradiatus disappeared with the entry of the second ice-rafted cycle (Backman, 1984). At Site 606, it is virtually impossible to decide from the abundance pattern (Fig. 1) whether the presence of $D$. pentaradiatus between 74.0 and $77.5 \mathrm{~m}$ sub-bottom results from sediment mixing or corresponds to a local low abundance caused by the onset of glacial conditions in the North Atlantic. This gives an uncertainty of as much as 0.1 m.y. $(2.33-2.43 \mathrm{Ma})$ for the last occurrence datum of $D$. pentaradiatus at Site 606. Similarly, the disappearance of $D$. surculus probably occurs between 77.0 and $78.5 \mathrm{~m}$ sub-bottom $(2.42-2.46 \mathrm{Ma})$.

\section{$D$. brouweri and D. triradiatus}

Takayama (1970) observed that $D$. triradiatus became common in the uppermost part of the range of $D$. brouweri, and Backman and Shackleton (1983) introduced a datum defined by the increase in the proportion $(>20 \%)$ of $D$. triradiatus relative to $D$. brouweri. The data of the latter authors did not allow a precise estimate of the duration of the peak abundance of $D$. triradiatus.

It appears from Figure 1 that the proportional increase of $D$. triradiatus began in an interval of low relative abundance of $D$. brouweri. Three samples were recounted $(606-8-4,60 \mathrm{~cm} ; 606-8-4,90 \mathrm{~cm} ; 606-8-4,120 \mathrm{~cm})$ in this critical $0.6-\mathrm{m}$ interval of low relative abundance of $D$. brouweri; the total abundance of both species reached 50 specimens in each. The results are plotted versus time and presented in Figure 2. The beginning of the D. triradiatus peak abundance has moved two sample levels upcore in Figure 2, as compared with the level indicated in Figure 1, following Backman and Shackleton's (1983) suggestion that the peak should be defined where $D$. triradiatus increases to $20 \%$ or more relative to $D$. brouweri. Using a depth of $58.7 \mathrm{~m}$ for the base of the Olduvai and $78.5 \mathrm{~m}$ for the top of the Gauss (Clement and Robinson, this volume) gives an age of $2.07 \mathrm{Ma}$ for the 


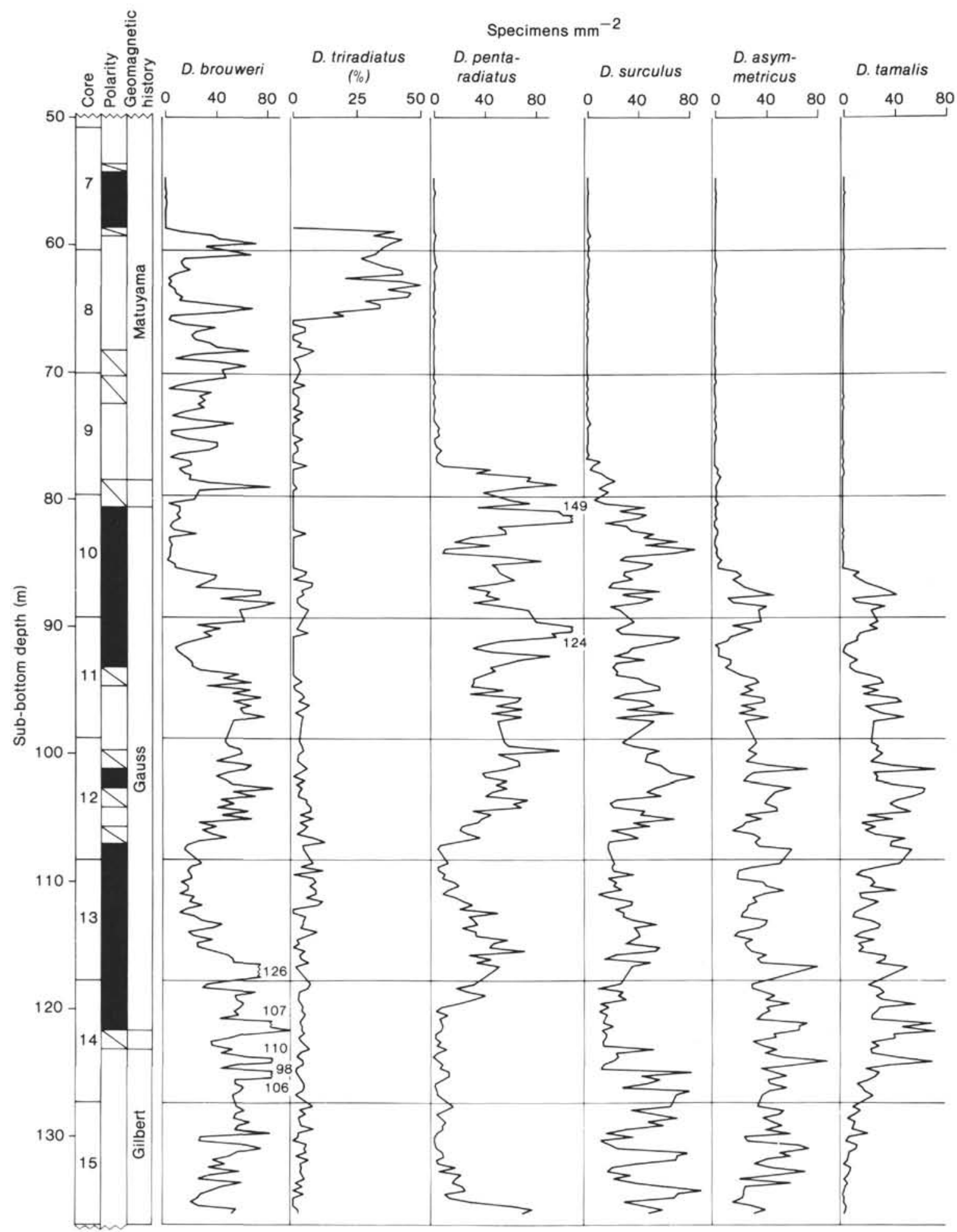

Figure 1. Abundance plots of $D$. brouweri, D. triradiatus, D. pentaradiatus, D. surculus, D. asymmetricus, and D. tamalis at DSDP Site 606 (Hole 606). The percentage of $D$. triradiatus was calculated relative to $D$. brouweri. Magnetostratigraphic polarity is shown (black = normal; white $=$ reversed); diagonals indicate uncertainty intervals of the boundaries. Each core boundary is drawn across the abundance plots. The biochronologic properties of these plots are discussed in the text.

beginning of the peak abundance; the entire peak abundance has a duration of approximately $190 \mathrm{kyr}$.

Figure 1 also shows that the simultaneous extinctions of $D$. brouweri and $D$. triradiatus occur in the short interval $(0.6 \mathrm{~m})$ of unknown magnetic polarity direction separating the base of the Olduvai from the underlying sediment of reversed polarity. Thus, an even closer sampling of this interval for a combined nannofossil and magnetostratigraphic study would probably indicate whether the final Discoaster extinction occurs immediately be- 


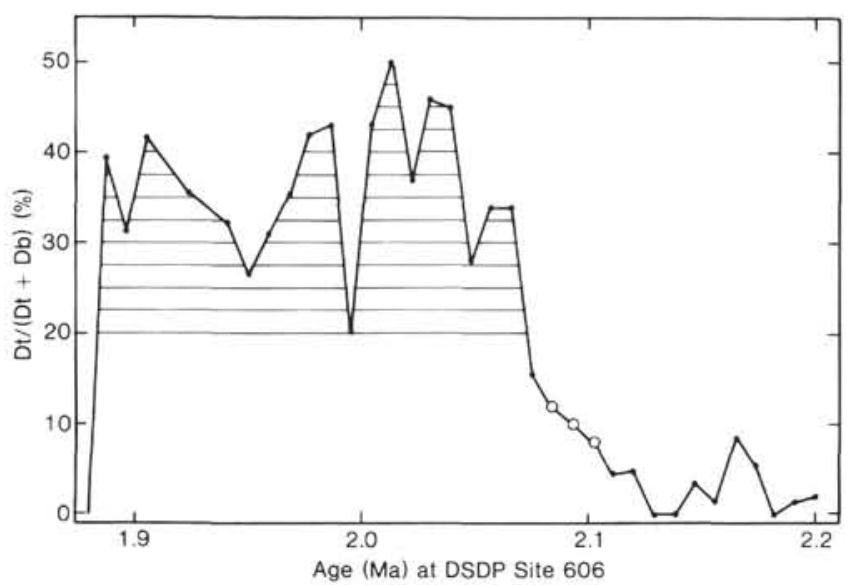

Figure 2. Interval of peak abundance of $D$. triradiatus. The three unfilled sample points represent recounted samples (see text). The abundance is expressed (in percent) as $D$. triradiatus (Dt) over $D$. triradiatus $+D$. brouweri $(\mathrm{Dt}+\mathrm{Db}) \times 100$. By definition, the peak abundance begins where the proportion of $D$. triradiatus increases to $20 \%$.

low, at, or immediately above the Olduvai/Matuyama boundary. If the extinction occurs precisely at the boundary, it would highlight the idea of Hays (1971), that changes in the geomagnetic field direction may cause extinctions among the marine microplankton.

Table 1 shows the age estimates of the Discoaster datums as determined at Site 606. It is noteworthy that the extinction of Reticulofenestra pseudoumbilica occurs between Samples 606-14-6, $149 \mathrm{~cm}$ and 606-15-1, $30 \mathrm{~cm}$, corresponding to an age of approximately $3.5 \mathrm{Ma}$.

\section{PALEOENVIRONMENTAL IMPLICATIONS}

Interpretations of paleoclimatic development via Discoaster abundance oscillations involve two assumptions: (1) nannofossils assigned to the genus Discoaster are remains of the calcareous nannoplankton that dwelt in the topmost layer of the water column; (2) the species considered did not change their general temperature preferences over the investigated period of time. Because of size, mineralogical composition, geographic distribution, abundance, etc., the first assumption is, to our knowledge, adopted by all present-day nannofossil specialists, so we consider this assumption uncontroversial. Quantitative data indicate that Discoaster species preferentially lived in the tropical to subtropical environment, that is, in warmer waters, throughout their roughly $60-\mathrm{m} . \mathrm{y}$. existence (see, e.g., Haq and Lohmann, 1976; Haq et al.,

Table 1. Summary of Pliocene Discoaster biochronology, DSDP Site 606.

\begin{tabular}{lll}
\hline \multicolumn{1}{c}{ Species } & Age (Ma) & Event \\
\hline D. brouweri & 1.89 & Extinction \\
D. triradiatus & 1.89 & Extinction \\
D. triradiatus & 2.07 & Peak abundance began \\
D. pentaradiatus & $2.33-2.43$ & Extinction \\
D. surculus & $2.42-2.46$ & Extinction \\
D. asymmetricus & 2.65 & Abundance decline \\
D. tamalis & 2.65 & Extinction \\
\hline
\end{tabular}

1977; Bukry, 1978; Lohmann and Carlson, 1981; Backman and Shackleton, 1983). Thus, Discoaster species must be considered stable as to their environmental preference, and an increased productivity at higher latitudes can be taken to indicate relatively warmer sea-surface temperatures. Consequently, we need to establish a measure of the productivity rate, or a measure proportional to this rate (i.e., accumulation rate). Our counting method provides values proportional to the absolute abundance (number of specimens per gram of sediment) (Backman and Shackleton, 1983). A measure proportional to the accumulation rate is obtained by multiplying the counted number of specimens per unit area in each sample by the sediment accumulation rate in the pertinent interval.

Figure 3 shows the time-dependent variation in Pliocene Discoaster accumulation at Site 606. An unusually high deep-sea sediment accumulation rate characterizes the Kaena subchron. Using Clement and Robinson's (this volume) magnetostratigraphic data, the rate is calculated to range between 7.1 and $11.4 \mathrm{~cm} / \mathrm{kyr}$., two to three times as much as in the adjacent intervals. Because the Kaena extends over a core boundary (the Core 606-11/ Core 606-12 boundary), we consider this high accumulation rate to be unrealistic, probably reflecting a problem caused by recoring (see Ruddiman et al., this volume, and Monechi et al., 1985, for discussion of various types of coring problems associated with the hydraulic piston coring technique). Plotting age-depth relationships of all magnetostratigraphic reversal boundaries from the base of the Olduvai to the base of the Mammoth shows that these, except the top of the Kaena, fall on a straight line. Taking into account the uncertainties in sub-bottom depth of the reversal boundaries and the less than full recovery of the critical Core 60611 , it becomes obvious that if a meter of sediment is considered recored, and thus a meter is subtracted from the depth interval of the Kaena, all reversal boundaries from the base of the Olduvai to the base of the Mammoth will fall on a straight line.

For the construction of Figure 3, the following magnetostratigraphic control points have been used: base of Olduvai, top of Gauss, base of Kaena, top of Mammoth, and base of Mammoth (thus excluding top Kaena). Although this provides an accumulation rate which slightly deviates from the true rate between the base of the Olduvai and the top of the Kaena (roughly $9 \%$ too high), we consider that this uniform rate represents the best available approximation of the actual depositional history between the base of the Olduvai and the base of the Mammoth. This rate is $3.69 \mathrm{~cm} / \mathrm{kyr}$., and the sediment accumulation rate below the base of the Mammoth is $6.67 \mathrm{~cm} / \mathrm{kyr}$., as determined from the base of the Mammoth, base of the Gauss, and top of the Cochiti.

The móst obvious patterns in Figure 3 are the shortterm variations, which occur as an overprint on a general trend showing decreasing abundances with decreasing age. Because the six species investigated occurred together only before $2.65 \mathrm{Ma}$, that part of the record is not strictly comparable with the younger part. But even 


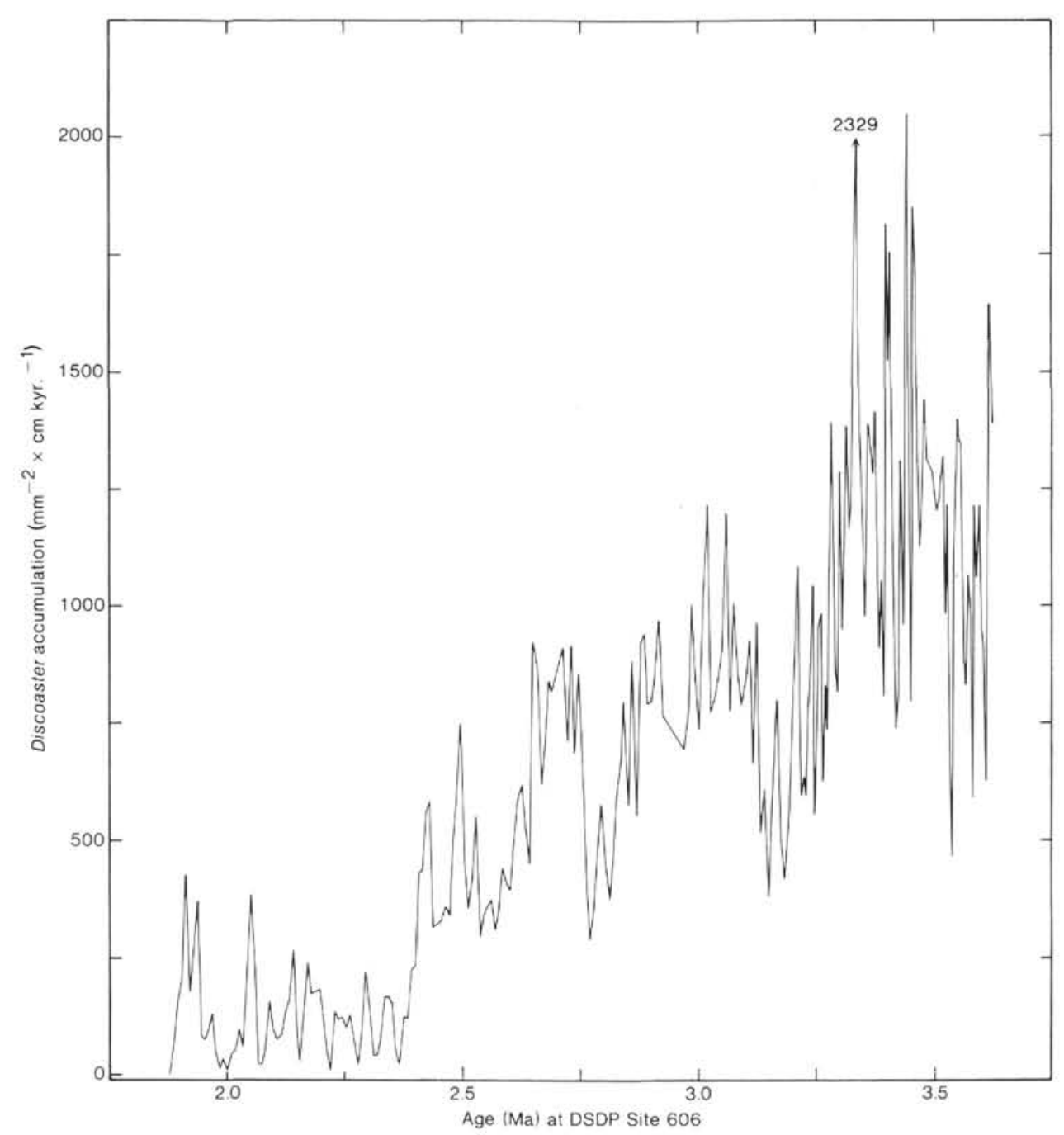

Figure 3. Plots of total Discoaster accumulation versus time. Notice the trend of decreasing accumulation with decreasing age and the overprint of short-term oscillations. See text for discussion of time control used and the implications of these two accumulation patterns.

so, the patterns are similar also if the pre-2.65-Ma record is viewed alone. First, the general trend of decreasing accumulation is seen as reflecting a progressive cooling of sea-surface temperatures at Site 606. This occurred before the large-scale continental glacial and interglacial cycles began to influence the climatic and sediment accumulation patterns in the mid- and high-latitude North Atlantic at about 2.4 Ma (Shackleton et al., 1984). Second, distinct short-term temperature fluctuations occurred throughout the long-term trend of cooling, including the preglacial period.

\section{Spectral Analysis}

Oxygen-isotope fluctuations, faunal data, and variations in sedimentological parameters have been used to demonstrate that the late Cenozoic paleoclimates varied at periodicities corresponding to the orbital parameters (e.g., Hays et al., 1976; Moore et al., 1982; Pisias and Leinen, 1984). Indeed, the theory of orbital forcing of paleoclimates permitted Imbrie et al. (1984) to establish the most highly resolved chronology available today for the last million years of Earth history, using the marine oxygen-isotope record.

Many calcareous nannoplankton species, or groups of species, are confined to specific temperature regimes (e.g., McIntyre, 1967; McIntyre and Bé, 1967; McIntyre et al., 1970; Okada and Honjo, 1973; Roche et al., 1975; Okada and McIntyre, 1979). Some of these authors used paleobiogeographic migrations of nannofossils to map changes in sea-surface temperature. It would be surprising if temperature-sensitive nannofossils did not oscillate in coherence with the orbitally forced temperature changes, considering a stratigraphic sequence at one oceanic site.

Backman et al. (in press) demonstrated that shortterm Discoaster abundance oscillations occurred between 1.9 and $3.5 \mathrm{Ma}$ in DSDP Hole $552 \mathrm{~A}\left(56^{\circ} \mathrm{N}\right.$ in the North Atlantic), at a periodicity corresponding to obliquity-induced insolation changes. The combined effect of sample spacing and the relatively low sediment accumulation rates prevented identification of the expected precessional peaks in the data set of Hole 552A, except in a 
short interval having a higher accumulation rate. The high sediment accumulation rates at Site 606 should permit identification of all orbital elements, with minor risk that the precessional peaks have been blurred by bioturbation.

The result of the spectral analysis is shown in Figures 4A and 4B. The spectrum in Figure 4A exhibits a strong spectral peak corresponding to a periodicity of approximately 386 kyr. Other spectral peaks have been detected at around 58, 38, 31, 24, and $15.5 \mathrm{kyr}$. The most distinct and significant of these peaks are those at 386,38 , and $24 \mathrm{kyr}$., as suggested by the maximum entropy spectrum (Fig. 4B). Within the bandwidth used, these peaks may be interpreted as corresponding to the 413-kyr. eccentricity period, the $41-\mathrm{kyr}$. obliquity period, and the precessional bimodal peaks having periods of 23 and $19 \mathrm{kyr}$., respectively. These latter peaks are not separated in our record. The peaks at 58,31 , and 15.5 kyr. may correspond to secondary astronomical periods predicted by Berger in 1977 (59, 31, and $15 \mathrm{kyr}$ ), or may represent harmonics or shifted peaks resulting from variability in the sediment accumulation rates not accounted for in the age model used. We conclude that the orbital forcing of paleoclimatic change is strongly imprinted in the Discoaster record at the latitude of Site 606.
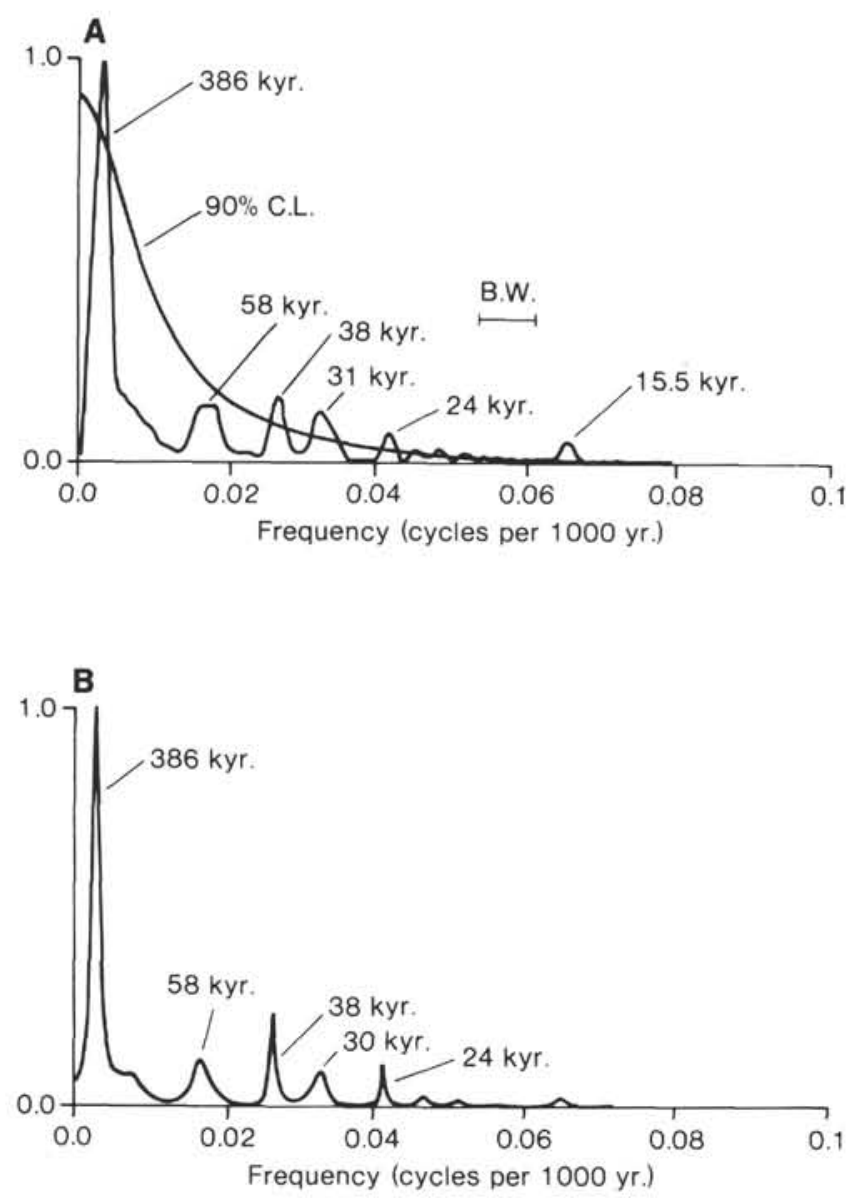

Figure 4. A. Spectral power density estimated on the entire Discoaster data set. B.W. indicates band width (Tukey window) and $90 \%$ C.L. is the upper red-noise confidence limit around the spectral peaks. B. Maximum entropy spectrum for the same record.

\section{DISCUSSION}

The relative importance of the main orbital elements varies as a function of the period of time considered (e.g., Berger, 1977; 1984). For example, Hays et al. (1976) revealed the dominant influence of the roughly 100-kyr. eccentricity period on the growth and decay of late Pleistocene ice sheets. Moore et al. (1982) and Dunn (1982) demonstrated a significant influence of the 400-kyr. eccentricity period in mid-Pliocene and late Miocene carbonate records from the Pacific. Interestingly, when Moore and others tuned their Miocene carbonate record with respect to the 400-kyr. period, they also obtained significant spectral peaks at 135 and $92 \mathrm{kyr}$. Thus, it is possible that our Discoaster record from Site 606 contains a similar, less prominent eccentricity signal corresponding to the period of roughly $100 \mathrm{kyr}$. It appears clear, however, that the results of Moore et al. (1982), Dunn (1982), and this study indicate a greater paleoclimatic impact of the 400-kyr. eccentricity period, as compared with the 100-kyr. period, during Pliocene and late Miocene times.

The 41-kyr. obliquity period has a dominant influence on the Discoaster record at DSDP Hole 552A, in contrast to the dominance of the 400-kyr. period at Site 606 . There is a difference of nearly $20^{\circ}$ latitude between these two sites. In view of the different impact the main orbital elements exert as a function of latitude (e.g., Berger and Pestiaux, 1984; Ruddiman and McIntyre, 1984), the results from the two sites are considered to be consistent.

The 400-kyr. period in the Discoaster record at Site 606 displays a cyclicity, characterized by decreased surface water temperatures, at 3.5-3.6, 3.1-3.2, 2.7-2.8 and 2.3-2.4 Ma (and possibly $1.9 \mathrm{Ma}$ ) (Figs. 3 and 4). Three of these events $(2.4,2.8,3.2 \mathrm{Ma})$ are clearly visible also in the record at Hole 522A (Backman et al., in press, fig. 3). Leonard et al. (1983) also observed this cyclicity in the southwestern Atlantic, as positive excursions in foraminiferal oxygen-isotope composition. Despite the lack of a phase relationship between their planktonic and benthic oxygen-isotope records, Leonard et al. interpreted the major events in terms of ice volume changes. This interpretation is not compatible with the data presented by Shackleton and Opdyke (1973). Moreover, the pre-2.4-Ma events cannot be associated with major glaciations in the northern North Atlantic or surrounding regions (Shackleton et al., 1984), although the 3.1-3.2 $\mathrm{Ma}$ and 3.5-3.6 Ma events are associated with some ice formation in high-altitude areas in California (Curry, 1966), Iceland (McDougall and Wensink, 1966), and South America (Mercer, 1976).

Moore et al. (1982) and Dunn (1982) suggested that the 400-kyr. period is associated with Antarctic glacial volume changes during Pliocene and Miocene times. The isotopic data presented by Leonard et al. (1983), however, seem to suggest that the volume changes of the Antarctic ice sheet during mid-Pliocene times were relatively small, since no isotopic phase relationship was confirmed between the benthic and planktonic foraminifers. This interpretation is supported by oxygen-isotope data derived from DSDP Site 284 in the Tasman Sea (Kennett et al., 1979). In that record, the only suggestion of a 
pre-2.4-Ma phase relationship between planktonic and benthic foraminifers occurred at about $3.5-3.6 \mathrm{Ma}$, at about the extinction level of $R$. pseudoumbilica (see the foregoing and Backman and Shackleton, 1983, for a chronological estimate of this event). With an analytical precision of $\pm 0.1 \%$, it is fair to say that the 0.16 to $0.24 \%$ enrichment which Kennett and others observed in the benthic record at about 3.5 to $3.6 \mathrm{Ma}$ appears negligible in terms of glacial buildup. In contrast, the concomitant 0.4 to $0.5 \%$ enrichment in the planktonic record seems to indicate a clearly defined temperature decrease of surface waters.

We thus agree with the conclusion of Shackleton et al. (1984), that the middle part of the Pliocene was characterized by considerable climatic variability, which subsequently led to the onset of the Northern Hemisphere glacial and interglacial cycles at about $2.4 \mathrm{Ma}$. The results of this study imply, however, that the wealth of paleontological, sedimentological, and oxygen-isotope evidence of deterioration of paleoclimatic conditions in the deep-sea environment before 2.4 Ma (e.g., Shackleton and Opdyke, 1977; Ledbetter et al., 1978; Keigwin and Thunell, 1979; Kennett et al., 1979; Hodell et al., 1983) reflect distinct temperature variations rather than the waxing and waning of major ice sheets in Antarctica or in the northern North Atlantic region. These temperature oscillations appear to have occurred in coherence with orbital elements, and the 400-kyr. eccentricity period played a dominant role. Indeed, the initiation of the socalled Northern Hemisphere glaciation coincided perfectly with the cyclicity of the $400-\mathrm{kyr}$. period, as suggested by the Discoaster record at Site 606 .

\section{SUMMARY}

Closely spaced sample intervals and quantitative methods of investigation are of paramount importance in achieving highly resolved biochronological estimates of evolutionary exits or entries in the deep-sea sediment record. Results from the Pliocene at Site 606, representing a sequence with a high sediment accumulation rate, indicate that uncertainties of less than $0.02 \mathrm{~m}$.y. may be obtained. The abundance data of six Pliocene Discoaster species suggest that four of these provide sharply defined events $(D$. brouweri, $1.89 \mathrm{Ma} ; D$. triradiatus, 1.89 $\mathrm{Ma}$; D. asymmetricus, $2.65 \mathrm{Ma}$; D. tamalis, $2.65 \mathrm{Ma}$ ), whereas two provide only approximative estimates $(D$. pentaradiatus, 2.33-2.43 Ma; D. surculus, 2.42-2.46 $\mathrm{Ma})$. The datum provided by the increase in the proportion of $D$. triradiatus relative to $D$. brouweri is, for the first time, determined accurately; the age of this event is $2.07 \mathrm{Ma} \pm 0.01 \mathrm{Ma}$.

The total accumulation of Discoaster species at Site 606 reveals two patterns: a long-term trend of decreasing abundance with decreasing age, and an overprint of short-term oscillations. Spectral analysis shows that the latter pattern has peaks corresponding to the main orbital elements, namely an eccentricity peak (413 kyr.), an obliquity peak (41 kyr.), and a precessional peak ( 23 and 19 kyr.; these are not separated in our record). In spite of the inherent uncertainties in our data set, and because the obliquity period has been detected in a similar Pliocene data set from a different environmental set- ting (DSDP Hole 552A), we conclude that the orbital forcing of paleoclimatic change is strongly imprinted in the Pliocene Discoaster record of the North Atlantic Ocean. The long-term trend of decreasing accumulation thus implies a progressive decrease in preglacial sea-surface temperature. The many indications of climatic deterioration at about $2.8,3.2$, and $3.6 \mathrm{Ma}$ cannot, at present, be associated with major glacial buildup. The Discoaster record from Site 606 suggests that these events represent temperature changes coinciding with the 413kyr. eccentricity period. The initiation of full-scale glacial conditions in the northern North Atlantic region at about $2.4 \mathrm{Ma}$ also fits into this cyclicity.

\section{ACKNOWLEDGMENTS}

We thank the Deep Sea Drilling Project and the shipboard scientific party of Leg 94 for the opportunity to do this study. Particularly, we appreciate the generosity with which Brad Clement shared his paleomagnetic data. Financial support for J. B. was provided by the Swedish Natural Science Research Council. Part of the spectrum analysis made by P. P. was supported by the Commission of European Communities under grant STI-004-J-C (CD). The constructive reviews made by Marie-Pierre Aubry, André Berger, and Ellen Thomas are gratefully acknowledged.

\section{REFERENCES}

Backman, J., 1984. Cenozoic calcareous nannofossil biostratigraphy from the northeastern Atlantic Ocean-Deep Sea Drilling Project Leg 81. In Roberts, D. G., Schnitker, D., et al., Init. Repts. DSDP, 81: Washington (U.S. Govt. Printing Office), 403-428.

Backman, J., Pestiaux, P., Zimmerman, H., and Hermelin, O., in press. Pliocene paleoclimatic and palaeo-oceanographic development in the North Atlantic: Discoaster abundance and coarse fraction data. Spec. Pap. Geol. Soc. London.

Backman, J., and Shackleton, N. J., 1983. Quantitative biochronology of Pliocene and early Pleistocene calcareous nannofossils from the Atlantic, Indian and Pacific oceans. Mar. Micropaleontol., 8: 141-170.

Berger, A., 1977. Support for the astronomical theory of climatic change. Nature, 269:44-45.

1984. Accuracy and frequency stability of the Earth's orbital elements during the Quaternary. In Berger, A., Imbrie, J., Hays, J., Kukla, G. and Saltzman, B. (Eds.), Milankovitch and Climate, I: Dordrecht (D. Riedel Publ. Co.), NATO ASI Ser. C, 126:3-40.

Berger, A., and Pestiaux, P., 1984. Accuracy and stability of the Quaternary terrestrial insolation. In Berger, A., Imbrie, J., Hays, J., Kukla, G. and Saltzman, B. (Eds.) Milankovitch and Climate, I: Dordrecht (D. Riedel Publ. Co.), NATO ASI Ser. C, 126:85-112.

Bukry, D., 1973. Low-latitude coccolith biostratigraphic zonation. In Edgar, N. T., Saunders, J. B., et al., Init. Repts. DSDP, 15: Washington (U.S. Govt. Printing Office), 685-703.

, 1978. Biostratigraphy of Cenozoic marine sediment by calcareous nannofossils. Micropaleontol., 24:44-60.

Curry, R. R., 1966. Glaciation about 3,000,000 years ago in the Sierra Nevada. Science, 154:770-771.

Dunn, D. A., 1982. Change from "Atlantic-type" to "Pacific-type" carbonate stratigraphy in the middle Pliocene equatorial Pacific Ocean. Mar. Geol., 50:41-60.

Haq, B. U., and Lohmann, G. P., 1976. Early Cenozoic calcareous nannoplankton biogeography of the Atlantic Ocean. Mar. Micropaleontol., 1:119-194.

Haq, B. U., Lohmann, G. P., and Wise, S. W., 1977. Calcareous nannoplankton biogeography and its paleoclimatic implications: Cenozoic of the Falkland Plateau (DSDP Leg 36) and Miocene of the Atlantic Ocean. In Barker, P., Dalziel, I. W. D., et al., Init. Repts. DSDP, 36: Washington (U.S. Govt. Printing Office), 745-759.

Hays, J. D., 1971. Faunal extinctions and reversals of the Earth's magnetic field. Geol. Soc. Am. Bull., 82:2433-2447.

Hays, J. D., Imbrie, J., and Shackleton, N. J., 1976. Variations in the Earth's orbit: Pacemaker of the ice ages. Science, 194:1121-1132.

Hodell, D. A., Kennett, J. P., and Leonard, K. A., 1983. Climatically induced changes in vertical water mass structure of the Vema Chan- 
nel during the Pliocene: Evidence from Deep Sea Drilling Project Holes 516A, 517, and 518. In Barker, P. F., Carlson, R. L., Johnson, D. A., et al., Init. Repts. DSDP, 72: Washington (U.S. Govt. Printing Office), 907-919.

Imbrie, J., Hays, J. D., Martinson, D. G., McIntyre, A., Mix, A. C., et al., 1984. The orbital theory of Pleistocene climate: Support from a revised chronology of the marine delta ${ }^{18} \mathrm{O}$ record. In Berger, A., Imbrie, J., Hays, J., Kukla, G., and Saltzman, B. (Eds.), Milankovitch and Climate, I: Dordrecht (D. Riedel Publ. Co.), NATO ASI Ser. C, 126:269-306.

Keigwin, L. D., and Thunell, R. C., 1979. Middle Pliocene climatic change in the western Mediterranean from faunal and oxygen isotopic trends. Nature, 282:294-296.

Kennett, J. P., Shackleton, N. J., Margolis, S. V., Goodney, D. E., Dudley, W. C., et al., 1979. Late Cenozoic oxygen and carbon isotopic history and volcanic ash history: DSDP Site 284 , South Pacific. Am. J. Sci., 279:52-69.

Ledbetter, M. T., Williams, D. F., and Ellwood, B. B., 1978. Late Pliocene climate and southwest Atlantic abyssal circulation. Nature, 272:237-239.

Leonard, K. A., Williams, D. F., and Thunell, R. C., 1983. Pliocene paleoclimatic and paleoceanographic history of the South Atlantic Ocean: Stable isotope records from Leg 72 Deep Sea Drilling Project Holes 516A and 517. In Barker, P. F., Carlson, R. L., Johnson, D. A., et al., Init. Repts. DSDP, 72: Washington (U.S. Govt. Printing Office), 895-906.

Lohmann, G. P., and Carlson, J. J., 1981. Oceanographic significance of Pacific late Miocene calcareous nannoplankton. Mar. Micropaleontol., 6:553-579.

McDougall, I., and Wensink, H., 1966. Paleomagnetism and geochronology of the Pliocene-Pleistocene lavas in Iceland. Earth Planet. Sci. Lett., 1:232-236.

McIntyre, A., 1967. Coccoliths as paleoclimatic indicators of Pleistocene glaciation. Science, 158:1314-1317.

McIntyre, A., and Bé, A. W. H., 1967. Modern coccolithophoridae of the Atlantic Ocean - I. Placoliths and cyrtoliths. Deep-Sea Res., 14:561-597.

McIntyre, A., Bé, A. W. H., and Roche, M. B., 1970. Modern Pacific coccolithophorida: A paleontological thermometer. Trans. N.Y. Acad. Sci., 32:720-731.

Mercer, J. H., 1976. Glacial history of southernmost South America. Quat. Res., 6:125-166.
Monechi, S., Bleil, U., and Backman, J., 1985. Magnetobiochronology of Late Cretaceous-Paleogene and late Cenozoic pelagic sedimentary sequences from the southwest Pacific (DSDP Leg 86, Site 577). In Heath, G. R., Burckle, L. H., et al., Init. Repts. DSDP, 86: Washington (U.S. Govt. Printing Office), 787-797.

Moore, T. C., Pisias, N. G., and Dunn, D. A., 1982. Carbonate time series of the Quaternary and late Miocene sediments in the Pacific Ocean: A spectral comparison. Mar. Geol., 46:217-233.

Okada, H., and Honjo, S., 1973. The distribution of oceanic coccolithophorids in the Pacific. Deep-Sea Res., 20:355-374.

Okada, H., and McIntyre, A., 1979. Seasonal distribution of modern coccolithophores in the western North Atlantic Ocean. Mar. Biol., 54:319-328.

Pisias, N. G., and Leinen, M., 1984. Milankovitch forcing of the oceanic system: Evidence from the northwest Pacific. In Berger, A., Imbrie, J., Hays, J., Kukla, G., and Saltzman, B. (Eds.), Milankovitch and Climate, I: Dordrecht (D. Riedel Publ. Co.), NATO ASI Ser. C, 126:307-330.

Roche, M. B., McIntyre, A., and Imbrie, J., 1975. Quantitative paleooceanography of the late Pleistocene-Holocene North Atlantic: Coccolith evidence. In Saito, T., and Burckle, L. H. (Eds.), Late Neogene Epoch Boundaries: New York (Micropaleontol. Press), pp. 199-225.

Ruddiman, W. F., and McIntyre, A., 1984. Ice-age thermal response and climatic role of the surface Atlantic Ocean, $40^{\circ} \mathrm{N}$ to $63^{\circ} \mathrm{N}$. Geol. Soc. Am. Bull., 95:381-396.

Shackleton, N. J., Backman, J., Zimmerman, H. G., Kent, D. V., Hall, M. A., et al., 1984. Oxygen isotope calibration of the onset of ice-rafting and history of glaciation in the North Atlantic region. Nature, 307:320-323.

Shackleton, N. J., and Opdyke, N. D., 1973. Oxygen isotope and paleomagnetic stratigraphy of equatorial Pacific Core V28-238: Oxygen isotope temperatures and ice volume changes on a $10^{5}$-year and $10^{6}$-year scale. Quat. Res., 3:39-55.

, 1977. Oxygen isotope and paleomagnetic evidence for early Northern Hemisphere glaciation. Nature, 270:216-219.

Takayama, T., 1970. The Pliocene-Pleistocene boundary in the Lamont Core V21-98 and at le Castella, southern Italy. J. Mar. Geol, 6:70-77.

Date of Initial Receipt: 11 January 1985

Date of Acceptance: 25 February 1985 